\title{
Effect of previous ascorbic acid treatment on the fatty acid profile of cobia (Rachycentron canadum) fillets during frozen storage
}

\author{
By S. Taheri', A. A. Motallebi ${ }^{2}$, A. Fazlara ${ }^{3}$, Y. Aftabsavar ${ }^{4}$ and S. P. Aubourg ${ }^{5}$ \\ 1'Iranian PhD student. Department of Food Processing Technology, State Agrarian University \\ of Armenia, Yerevan, Armenia. \\ ${ }^{2}$ Iranian Fisheries Research Organization, Tehran, Iran. \\ ${ }^{3}$ Faculty of Veterinary Medicine, Shahid Chamran University of Ahvaz, Ahvaz, Iran. \\ ${ }^{4}$ Persian Gulf and Oman Sea Ecology Research Centre, Bandar Abbas, Iran. \\ ${ }^{5}$ Department of Food Technology, Instituto de Investigaciones Marinas (CSIC), Vigo, Spain. \\ ${ }^{*}$ Corresponding author: saubourg @iim.csic.es
}

\section{RESUMEN}

\begin{abstract}
Efecto de un tratamiento previo con ácido ascórbico sobre el perfil de ácidos grasos de filetes de cobia (Rachycentron canadum) conservada en congelación.
\end{abstract}

Este estudio se centra en el valor nutricional lipídico de cobia (Rachycentron canadum) congelada. Para ello, se investiga el efecto que un tratamiento previo con ácido ascórbico (AA) puede tener sobre el perfil de ácidos grasos de filete de pescado durante su conservación en congelación $\left(-18{ }^{\circ} \mathrm{C}\right.$; seis meses). Se aplicaron dos concentraciones de AA $(0.25 \%$ y $0.50 \%)$ que fueron comparadas con muestras control. Como resultado de la conservación en congelación, se observó un descenso importante en grupos de ácidos grasos monoinsaturados, poliinsaturados y poliinsaturados de las serie $n-3$, así como en la relación n-3/n-6. Sin embargo, el tratamiento previo con AA produjo un efecto protector en estos parámetros, siendo mayor al aplicar AA en la concentración superior. La medida del índice de polienos reflejó un incremento de la oxidación lipídica durante la conservación en congelación; este incremento fue parcialmente inhibido como resultado del tratamiento previo con $\mathrm{AA}$.

PALABRAS CLAVE: Ácido ascórbico - Ácidos grasos - Congelación - Nutrición - Oxidación - Rachycentron canadum.

\section{SUMMARY}

Effect of previous ascorbic acid treatment on the fatty acid profile of cobia (Rachycentron canadum) fillets during frozen storage.

The present research focuses on the nutritional value of the lipid retention associated with frozen cobia (Rachycentron canadum). The effect of a previous soaking in an aqueous ascorbic acid (AA) solution on the fatty acid profile of fish fillets during a further frozen storage period $\left(-18^{\circ} \mathrm{C}\right)$ was investigated. Two different AA concentrations were tested $(0.25 \%$ and $0.50 \%)$ and compared to control conditions. As a result of the frozen storage period (up to 6 months), marked decreases were found in the contents of fatty acid groups such as monounsaturated, polyunsaturated and $n-3$ polyunsaturated, as well as in the $n-3 / n-6$ ratio. However, a preserving effect on such fatty acid parameters could be observed resulting from the previous AA treatment, which was greater when applying the $0.50 \%$ AA concentration. Assessment of the polyene index indicated an increased lipid oxidation development during the frozen storage time; this increase was partially inhibited by the previous AA soaking.

KEY-WORDS: Ascorbic acid - Fatty acids - Frozen storage - Nutrition - Oxidation - Rachycentron canadum.

\section{INTRODUCTION}

Polyunsaturated fatty acids (PUFA) corresponding to the $n-3$ series have attracted increasing attention because of their benefitial role in human health and nutrition (Ackman, 1990; RubioRodríguez et al., 2010). Marine organisms are recognized as the most important sources of such fatty acids, arising from the marine phytoplankton as the primary producer, then following the tropic chain up to marine invertebrates and fish (Pearson et al., 1977; Green and Selivonchick, 1987). However, PUFA oxidation during marine food processing has shown to lead to the formation of a wide variety of lipid oxidation products which can ultimately contribute to the loss of essential nutrients and detrimental sensory quality (Harris and Tall, 1994; Aubourg, 1999; Chaouqy et al., 2008). In order to minimize such undesirable effects, different technological strategies have been applied such as low temperature storage, preserving packaging, glazing, including protecting chemicals and the incorporation of antioxidants (Davies, 1997; Lin and Lin, 2005; Medina et al., 2009).

One of the most commonly employed preserving technologies has been the addition of antioxidant compounds. Since synthetic antioxidants have been reported to behave as carcinogen and mutating agents, more attention has been directed to the employment of natural antioxidants (Decker, 1998). Among natural antioxidants, ascorbic acid (AA) is a low molecular weight organic acid that represents a good choice because of its easy availability, low commercial cost and wide range of 
permitted concentrations for its use (Madrid et al., 1994; Giese, 1996). Thus, AA is widely known for its role as chelator and acidulant in biological systems and as a synergist of primary antioxidants, so that a positive effect on shelf life increase has been described for marine oils (Hamilton et al., 1998), minced fish (Hwang and Regenstein, 1988), fish fillets (Kilinc et al., 2009; Pourashouri et al., 2009) and whole fish (Aubourg et al., 2004; Sanjuás et al., 2011).

Cobia (Rachycentron canadum) fish is the only species in the family Rachycentridae. Cobia is a promising candidate for aquaculture trade because of its rapid growth rate, reaching up to $4-6 \mathrm{~kg}$ in a year, hardiness, efficient feed conversion, excellent flesh quality and comparatively low production costs (Franks et al., 1999; Liao et al., 2004). Therefore, research has been recently carried out to assess the optimal commercial feeds to be employed (Xiao et al., 2010; Trushenski et al., 2011). Related to cobia composition studies, previous research has focused on proximate analysis (Duncan et al., 2007; Liu et al., 2009) and fatty acid composition description (Khristoferzen, 1969; Kotb et al., 1991; Liu et al., 2009). Additionally, cobia skin gelatine hydrolysates have been investigated because of their antioxidant properties (Chow et al., 2011; Yang et al., 2008) and the HACCP system has been applied to frozen cobia fillets (Xia et al., 2009).

The present study focuses on the retention of the lipid nutritional value of this species when commercialized as a frozen product. The effect of a previous soaking in an aqueous $A A$ solution on the fatty acid composition during a further frozen storage period was investigated.

\section{MATERIAL AND METHODS}

\subsection{Sample preparation}

Fresh cobia (Rachycentron canadum; 20 individual fish) were caught in the Persian gulf near Bandar Abbas (Hormozgan, South Iran), surrounded by ice in boxes and transferred for processing to the Persian Gulf and Oman Sea Ecology Research Center after 8 hours of being caught. Upon arrival, the cobia fish was processed immediately in a cold room $\left(4{ }^{\circ} \mathrm{C}\right)$. The average length and weight of the specimens were $92.23 \pm 1.04 \mathrm{~cm}$ and $5.32 \pm 1.02 \mathrm{~kg}$, respectively. Fish samples were beheaded, gutted, filleted by hand without separating the skin and carefully washed with cold water. The weight of each fillet was $200 \pm 5 \mathrm{~g}$. Then the fillets were divided into 3 groups. Samples of the first group were left untreated (control) and directly packaged in polyamide/polyethylene bags. Fillets belonging to the second group were immersed in a $0.25 \%$ aqueous solution of AA (0.25-AA treatment); after 5 minutes, fillets were removed and packaged in individual polyamide/polyethylene bags. Finally, samples corresponding to the third group were immersed in a
$0.5 \%$ aqueous solution of $\mathrm{AA}$ (0.50-AA treatment); after 5 minutes, fillets were removed and packaged in individual polyamide/polyethylene bags. The total time elapsed for processing fish samples was 2 hours.

All packaged samples were immediately frozen at $-30^{\circ} \mathrm{C}$. After 24 hours, all the fish fillets were placed in $\mathrm{a}-18^{\circ} \mathrm{C}$ freezer. For all three groups of fish fillets, analyses were carried out after the freezing process $\left(0\right.$-month storage at $\left.-18^{\circ} \mathrm{C}\right)$, and after 1,3 and 6 months of storage at $-18^{\circ} \mathrm{C}$. In all cases, thawing was carried out by refrigerated storage $\left(4^{\circ} \mathrm{C}\right)$ overnight. For each kind of fillet, three different batches $(n=3)$ were considered and analyzed separately in order to achieve the statistical analysis. The AA employed was reagent grade (E. Merck, Darmstadt, Germany).

\subsection{Determination of proximate composition}

The moisture content of cobia flesh was determined by drying to constant weight at 102-105 ${ }^{\circ} \mathrm{C}$ for $24 \mathrm{~h}$, according to the AOAC (2005) standard method. Crude ash was determined after heating the sample overnight at $550{ }^{\circ} \mathrm{C}$ (AOAC, 2005). Crude protein content was determined by the Kjeldahl method (AOAC, 2005), employing the 6.25 conversion factor. Fillet fat content was determined by the AOAC (2005) method, this including acid hydrolysis followed by petroleum ether extraction.

In all cases, results are expressed as $\mathrm{g} / 100 \mathrm{~g}$ muscle.

\subsection{Fatty acid analysis}

Total lipids were extracted by a chloroformmethanol mixture, according to the Bligh and Dyer (1959) method. Lipid extracts were then saponified with $0.5 \mathrm{~N}$ methanolic $\mathrm{NaOH}$ and further transesterified with $\mathrm{BF}_{3}$ in methanol (AOAC, 2000).

The resulting fatty acid methyl esters (FAME) were analyzed on a Gas Chromatograph (DANI 1000) equipped with a Flame Ionization Detector (FID). The fatty acid esters were separated on a SGE column $(30 \mathrm{~m} \times 0.25 \mathrm{~mm}$ i.d.). Helium was employed as the carrier gas. The temperature and other chromatographic conditions employed were as follows: initial temperature $\left(175^{\circ} \mathrm{C}\right)$, heating rate $\left(1^{\circ} \mathrm{C} /\right.$ $\mathrm{min})$, final temperature $\left(220^{\circ} \mathrm{C}\right)$, end time (20 min), injector temperature $\left(250^{\circ} \mathrm{C}\right)$ and detector temperature $\left(270^{\circ} \mathrm{C}\right)$. FAME were identified by comparison of the retention times with those of standard mixtures (Larodan, Qualmix Fish; Supelco, FAME Mix). Peak areas were electronically integrated and quantified; results are expressed as percentage of total FAME. The polyene index (PI) was calculated as the following fatty acid concentration ratio: $(20: 5 n-3+$ 22:6n-3)/16:0.

\subsection{Statistical analysis}

Data $(n=3)$ obtained from the different proximate and FAME analyses were subjected to 
the ANOVA method ( $p<0.05)$ to explore differences in two different ways: AA treatment effect and frozen storage time effect (SPSS 16 software). Comparison of the means was performed using the Duncan's multiple range test $(p<0.05)$.

\section{RESULTS AND DISCUSSION}

\subsection{Proximate composition}

The proximate composition of the fish fillets was measured in the starting fish and in the samples corresponding to the 0-month frozen time of the three conditions (control, 0.25-AA and 0.50-AA). The average ( \pm standard deviation) cobia fillet values obtained for moisture, protein, fat and ash were $75.27 \pm 0.04,16.58 \pm 0.25,5.31 \pm 0.85$ and $0.97 \pm 0.10 \mathrm{~g} / 100 \mathrm{~g}$ muscle, respectively. No differences $(p>0.05)$ as a result of the freezing process could be outlined for any of the constituents under study; not even $(p>0.05)$ as a result of the previous AA treatment.

Previous research related to this species provided varying results according to the wild/ farmed condition, the capture location and the fish size. Thus, Khristoferzen (1969) obtained a 2.0 lipid content in wild cobia captured in the Indian ocean, while Kobt et al. (1991) obtained a $0.70 \%$ lipid content for wild cobia fish captured in the Persian gulf; in this research, individual fish were markedly small (450 g each). In a more detailed study, Liu et al. (2009) analyzed the lipid content in different tissues of farmed cobia (5-6 kg each individual); results obtained were $16.34 \pm 0.12,11.55 \pm 0.20$, $9.82 \pm 0.35,6.23 \pm 0.59$ and $2.89 \pm 0.10(\mathrm{~g} / 100 \mathrm{~g}$ muscle) for viscera, abdomen muscle, head, back muscle and skin, respectively.

\subsection{Fatty acid analysis}

Different individual fatty acids were identified and quantified in cobia muscle; the results obtained throughout a 6-month frozen storage period corresponding to treated (0.25-AA and 0.50-AA) and untreated (control) fish are shown in Tables 1-3. A great similarity in fatty acid profiles could be observed by comparison of the three kinds of samples. In all cases, the most abundant fatty acids were C16:0 (palmitic acid) and C18:1n-9 (oleic acid), followed by C18:0 (stearic acid). With regards to PUFA, C22:6n-3 (docosahexaenoic acid) and C18:2n-6 (linoleic acid) were found to be the most abundant.

The present results agree with those obtained by Liu et al. (2009) for cobia that was farmed in marine cages located offshore of the Hainan

Table 1

Evolution of fatty acid composition* in control cobia fillets during frozen storage ${ }^{\star *}$

\begin{tabular}{|c|c|c|c|c|}
\hline \multirow{2}{*}{ Fatty acid } & \multicolumn{4}{|c|}{ Frozen storage time (months) } \\
\hline & 0 & 1 & 3 & 6 \\
\hline C14:0 & $4.23 \pm 0.14 \mathrm{a}$ & $4.53 \pm 0.3 a$ & $5.45 \pm 0.05 b$ & $6.83 \pm 0.14 c$ \\
\hline C15:0 & $0.65 \pm 0.02 \mathrm{a}$ & $0.90 \pm 0.05 b$ & $1.40 \pm 0.01 c$ & $1.74 \pm 0.01 d$ \\
\hline C16:0 & $27.42 \pm 1.03 a$ & $28.07 \pm 0.07 a$ & $31.69 \pm 0.15 b$ & $33.87 \pm 0.17 c$ \\
\hline $\mathrm{C} 17: 0$ & $1.15 \pm 0.03 d$ & $0.92 \pm 0.02 c$ & $0.26 \pm 0.01 b$ & $0.15 \pm 0.05 a$ \\
\hline C18:0 & $12.62 \pm 0.54 \mathrm{c}$ & $12.1 \pm 0.10 \mathrm{c}$ & $10.11 \pm 0.12 b$ & $8.73 \pm 0.03 a$ \\
\hline C14:1n-5 & $0.71 \pm 0.01 \mathrm{c}$ & $0.69 \pm 0.01 c$ & $0.58 \pm 0.01 b$ & $0.31 \pm 0.01 \mathrm{a}$ \\
\hline C15:1n-5 & $0.67 \pm 0.04 c$ & $0.57 \pm 0.03 b$ & $0.55 \pm 0.01 b$ & $0.36 \pm 0.01 a$ \\
\hline C16:1n-7 & $4.91 \pm 0.10 c$ & $4.73 \pm 0.10 c$ & $3.91 \pm 0.04 b$ & $2.82 \pm 0.02 a$ \\
\hline C17:1n-7 & $0.93 \pm 0.03 d$ & $0.81 \pm 0.01 \mathrm{c}$ & $0.69 \pm 0.01 b$ & $0.39 \pm 0.02 a$ \\
\hline C18:1n-7 & $0.04 \pm 0.05$ & $N D^{\star \star *}$ & $N D^{* * *}$ & $N D^{\star * *}$ \\
\hline C18:1n-9 & $25.76 \pm 0.30 c$ & $25.38 \pm 0.08 c$ & $24.09 \pm 0.10 b$ & $22.02 \pm 0.99 a$ \\
\hline C20:1n-9 & $0.71 \pm 0.08 c$ & $0.62 \pm 0.02 c$ & $0.56 \pm 0.01 b$ & $0.36 \pm 0.01 a$ \\
\hline C18:2n-6 & $4.38 \pm 0.10 d$ & $4.08 \pm 0.08 c$ & $3.53 \pm 0.10 b$ & $2.55 \pm 0.02 a$ \\
\hline C18:3n-3 & $0.63 \pm 0.03 d$ & $0.56 \pm 0.01 c$ & $0.32 \pm 0.01 b$ & $0.15 \pm 0.05 a$ \\
\hline C20:2n-6 & $0.31 \pm 0.02 c$ & $0.25 \pm 0.01 b$ & $0.15 \pm 0.05 a$ & $0.10 \pm 0.01 \mathrm{a}$ \\
\hline C20:4n-6 & $2.56 \pm 0.06 a$ & $2.86 \pm 0.01 b$ & $3.20 \pm 0.10 c$ & $3.80 \pm 0.10 d$ \\
\hline C20:5n-3 & $1.80 \pm 0.05 d$ & $1.50 \pm 0.01 c$ & $1.19 \pm 0.01 b$ & $0.78 \pm 0.03 a$ \\
\hline C22:6n-3 & $5.76 \pm 0.02 d$ & $5.26 \pm 0.06 c$ & $4.18 \pm 0.01 b$ & $3.40 \pm 0.10 a$ \\
\hline
\end{tabular}

* Mean values of three independent determinations \pm standard deviation.

** For the same row, values followed by different letters $(a, b, c, d)$ denote significant $(p<0.05)$ differences.

*** ND: not detected. 
province (China). In this research, different tissue locations were analyzed so that all of them showed C18:1n-9 and C16:0 as the most abundant fatty acids; among PUFA, C22:6n-3 and C20:5n-3 (eicosapentaenoic acid) were predominant. The fatty acid profile of farmed cobia has recently been studied according to the effect of replacing dietary fish oil with soybean oil (Trushenski et al., 2011). In all cases of this experiment (from 0\% to 100\% of dietary oil replacement), the PUFA content (39.7-44.4\%) was found higher than in the present research. In contrast, the contents found for saturated fatty acids (SFA) (35.2-30.9\%) and monounsaturated fatty acids (MUFA) (25.1-24.7\%) were found markedly lower than in the present study.

Related to previous research on cobia fish belonging to wild conditions, the present results can be considered quite different. Kotb et al. (1991) found similar values for the four most abundant fatty acids (C22:6n-3, C16:0, C18:1n-9 and C18:0) in fish captured in the Qatari water of the Persian gulf. Similarly, Khristoferzen (1969) found a higher PUFA presence in wild fish from the Indian ocean when compared to the current study.

It is concluded that previous research on cobia fish agrees with previous research carried out on different kinds of fish species where lower contents in SFA and MUFA, but higher in PUFA have been obtained for wild fish by comparison with the farmed samples (Alasalvar et al., 2002; Aubourg et al., 2007; Álvarez et al., 2009). When compared to most wild fish species, the present results on the fatty acid profile of cobia fillets can be considered as having higher contents of SFA and MUFA, but lower contents of PUFA.

As for the lipid content, the fatty acid profile of fish flesh has shown to depend on a large number of internal and external factors already mentioned (Pearson et al., 1977; Watanabe, 1982; Greene and Selivonchick, 1987; Celik et al., 2005). Among the external factors, an important one to be taken into account in the present case should be water temperature. Temperature is known to be a critical factor for the well-being of fish (Pearson et al., 1977; Greene and Selivonchick, 1987). Changes in water temperature have been reported to induce a restructuring and a change in the fatty acid unsaturation of biological membranes in order to ensure appropriate cell membrane fluidity regardless of the water temperature. Long ago, it was discovered that poikilotherm fish increase the ratio PUFA/SFA in membrane lipids in response to lowered ambient temperatures and vice versa (Greene and Selivonchick, 1987); such a response has also been reported for different species such as

Table 2

Evolution during frozen storage of fatty acid composition* in cobia fillets previously treated with an aqueous $0.25 \%$ ascorbic acid solution**

\begin{tabular}{|c|c|c|c|c|}
\hline \multirow{2}{*}{ Fatty acid } & \multicolumn{4}{|c|}{ Frozen storage time (months) } \\
\hline & 0 & 1 & 3 & 6 \\
\hline C14:0 & $4.13 \pm 0.03 a$ & $4.31 \pm 0.01 \mathrm{~b}$ & $4.83 \pm 0.03 c$ & $5.36 \pm 0.03 c$ \\
\hline C15:0 & $0.61 \pm 0.01 \mathrm{a}$ & $0.86 \pm 0.01 b$ & $1.03 \pm 0.01 \mathrm{c}$ & $1.18 \pm 0.01 \mathrm{c}$ \\
\hline C16:0 & $27.41 \pm 0.13 a$ & $27.69 \pm 0.11 b$ & $30.08 \pm 0.08 c$ & $30.79 \pm 0.23 c$ \\
\hline C17:0 & $1.11 \pm 0.05 b$ & $1.04 \pm 0.01 \mathrm{~b}$ & $0.39 \pm 0.01 \mathrm{a}$ & $0.43 \pm 0.05 a$ \\
\hline C18:0 & $12.47 \pm 0.13 d$ & $12.19 \pm 0.04 \mathrm{c}$ & $10.54 \pm 0.03 b$ & $10.09 \pm 0.04 a$ \\
\hline C14:1n-5 & $0.72 \pm 0.02 \mathrm{~d}$ & $0.61 \pm 0.03 c$ & $0.46 \pm 0.02 b$ & $0.33 \pm 0.03 a$ \\
\hline C15:1n-5 & $0.64 \pm 0.01 \mathrm{~d}$ & $0.54 \pm 0.04 c$ & $0.34 \pm 0.01 \mathrm{~b}$ & $0.21 \pm 0.02 a$ \\
\hline C16:1n-7 & $4.78 \pm 0.05 c$ & $4.67 \pm 0.10 c$ & $4.07 \pm 0.03 b$ & $3.08 \pm 0.08 a$ \\
\hline C17:1n-7 & $0.94 \pm 0.02 \mathrm{~d}$ & $0.86 \pm 0.03 c$ & $0.73 \pm 0.01 b$ & $0.44 \pm 0.02 a$ \\
\hline C18:1n-7 & $0.05 \pm 0.01$ & $0.04 \pm 0.02$ & $0.05 \pm 0.02$ & $0.02 \pm 0.03$ \\
\hline C18:1n-9 & $25.90 \pm 0.10 c$ & $25.76 \pm 0.20 c$ & $25.36 \pm 0.10 b$ & $23.86 \pm 0.10 a$ \\
\hline C20:1n-9 & $0.70 \pm 0.01 c$ & $0.65 \pm 0.03 c$ & $0.58 \pm 0.02 b$ & $0.39 \pm 0.02 a$ \\
\hline C18:2n-6 & $4.37 \pm 0.03 \mathrm{~d}$ & $4.29 \pm 0.02 c$ & $3.84 \pm 0.04 b$ & $3.53 \pm 0.03$ \\
\hline C18:3n-3 & $0.62 \pm 0.02 \mathrm{~d}$ & $0.55 \pm 0.03 c$ & $0.42 \pm 0.02 b$ & $0.27 \pm 0.01$ \\
\hline C20:2n-6 & $0.34 \pm 0.03 c$ & $0.26 \pm 0.01 b$ & $0.13 \pm 0.01 \mathrm{a}$ & $0.11 \pm 0.05 a$ \\
\hline$C 20: 4 n-6$ & $2.53 \pm 0.10 \mathrm{a}$ & $2.65 \pm 0.05 b$ & $2.95 \pm 0.05 c$ & $3.18 \pm 0.01$ \\
\hline C20:5n-3 & $1.82 \pm 0.07 d$ & $1.68 \pm 0.08 c$ & $1.34 \pm 0.03 b$ & $1.04 \pm 0.02 a$ \\
\hline C22:6n-3 & $5.80 \pm 0.30 c$ & $5.48 \pm 0.13 c$ & $5.03 \pm 0.03 b$ & $4.55 \pm 0.05 a$ \\
\hline
\end{tabular}

* Mean values of three independent determinations \pm standard deviation.

${ }^{* *}$ For the same row, values followed by different letters $(a, b, c, d)$ denote significant $(p<0.05)$ differences. 
Table 3

Evolution during frozen storage of fatty acid composition* in cobia fillets previously treated with an aqueous $0.50 \%$ ascorbic acid solution ${ }^{\star \star}$

\begin{tabular}{lcccc}
\hline \multirow{2}{*}{ Fatty acid } & \multicolumn{4}{c}{ Frozen storage time (months) } \\
\cline { 2 - 5 } & 0 & 1 & 3 & 6 \\
\hline C14:0 & $4.07 \pm 0.05 \mathrm{a}$ & $4.27 \pm 0.02 \mathrm{~b}$ & $4.79 \pm 0.08 \mathrm{c}$ & $5.01 \pm 0.05 \mathrm{~d}$ \\
C15:0 & $0.64 \pm 0.01 \mathrm{a}$ & $0.84 \pm 0.01 \mathrm{~b}$ & $0.94 \pm 0.02 \mathrm{c}$ & $1.06 \pm 0.01 \mathrm{~d}$ \\
C16:0 & $27.58 \pm 0.13 \mathrm{a}$ & $27.80 \pm 0.12 \mathrm{a}$ & $28.67 \pm 0.07 \mathrm{~b}$ & $31.45 \pm 0.05 \mathrm{c}$ \\
C17:0 & $1.12 \pm 0.01 \mathrm{c}$ & $1.10 \pm 0.05 \mathrm{c}$ & $0.72 \pm 0.01 \mathrm{~b}$ & $0.33 \pm 0.01 \mathrm{a}$ \\
C18:0 & $12.72 \pm 0.02 \mathrm{~d}$ & $12.38 \pm 0.03 \mathrm{c}$ & $11.48 \pm 0.03 \mathrm{~b}$ & $9.88 \pm 0.02 \mathrm{a}$ \\
C14:1n-5 & $0.70 \pm 0.04 \mathrm{~d}$ & $0.64 \pm 0.02 \mathrm{c}$ & $0.49 \pm 0.02 \mathrm{~b}$ & $0.38 \pm 0.01 \mathrm{a}$ \\
C15:1n-5 & $0.73 \pm 0.03 \mathrm{~d}$ & $0.63 \pm 0.01 \mathrm{c}$ & $0.42 \pm 0.02 \mathrm{~b}$ & $0.31 \pm 0.01 \mathrm{a}$ \\
C16:1n-7 & $4.90 \pm 0.10 \mathrm{c}$ & $4.79 \pm 0.10 \mathrm{c}$ & $4.36 \pm 0.10 \mathrm{~b}$ & $3.80 \pm 0.10 \mathrm{a}$ \\
C17:1n-7 & $0.86 \pm 0.02 \mathrm{~b}$ & $0.91 \pm 0.02 \mathrm{~b}$ & $0.79 \pm 0.02 \mathrm{~b}$ & $0.62 \pm 0.02 \mathrm{a}$ \\
C18:1n-7 & $0.04 \pm 0.01 \mathrm{ab}$ & $0.05 \pm 0.01 \mathrm{~b}$ & $0.04 \pm 0.02 \mathrm{ab}$ & $0.02 \pm 0.01 \mathrm{a}$ \\
C18:1n-9 & $25.72 \pm 0.10 \mathrm{~b}$ & $25.64 \pm 0.20 \mathrm{~b}$ & $25.46 \pm 0.19 \mathrm{~b}$ & $24.27 \pm 0.10 \mathrm{a}$ \\
C20:1n-9 & $0.67 \pm 0.01 \mathrm{c}$ & $0.65 \pm 0.03 \mathrm{c}$ & $0.49 \pm 0.02 \mathrm{~b}$ & $0.41 \pm 0.01 \mathrm{a}$ \\
C18:2n-6 & $4.40 \pm 0.10 \mathrm{c}$ & $4.32 \pm 0.02 \mathrm{c}$ & $4.12 \pm 0.02 \mathrm{~b}$ & $3.66 \pm 0.05 \mathrm{a}$ \\
C18:3n-3 & $0.61 \pm 0.01 \mathrm{c}$ & $0.59 \pm 0.01 \mathrm{c}$ & $0.51 \pm 0.02 \mathrm{~b}$ & $0.33 \pm 0.02 \mathrm{a}$ \\
C20:2n-6 & $0.36 \pm 0.03 \mathrm{~d}$ & $0.30 \pm 0.01 \mathrm{c}$ & $0.25 \pm 0.02 \mathrm{~b}$ & $0.18 \pm 0.02 \mathrm{a}$ \\
C20:4n-6 & $2.53 \pm 0.03 \mathrm{a}$ & $2.55 \pm 0.03 \mathrm{a}$ & $2.71 \pm 0.06 \mathrm{~b}$ & $3.03 \pm 0.03 \mathrm{c}$ \\
C20:5n-3 & $1.74 \pm 0.04 \mathrm{c}$ & $1.68 \pm 0.08 \mathrm{c}$ & $1.50 \pm 0.05 \mathrm{~b}$ & $1.22 \pm 0.02 \mathrm{a}$ \\
C22:6n-3 & $5.79 \pm 0.07 \mathrm{~d}$ & $5.48 \pm 0.10 \mathrm{c}$ & $5.11 \pm 0.04 \mathrm{~b}$ & $4.80 \pm 0.10 \mathrm{a}$ \\
\hline
\end{tabular}

${ }^{*}$ Mean values of three independent determinations \pm standard deviation

** For the same row, values followed by different letters $(a, b, c, d)$ denote significant $(p<0.05)$ differences.

rainbow trout (Oncorhynchus mykiss; Ingemansson et al., 1993) and bonito (Euthynnus pelamis; Saito et al., 1997). Since cobia individuals employed in the present study were captured in relatively warm water (average water temperature $28.5^{\circ} \mathrm{C}$ ), it is believed that this effect has strongly influenced the fatty acid profile.

\subsubsection{Effect of frozen storage}

Frozen storage led to important changes in the fatty acid profile in all three kinds of fillets (Tables 1-3). The treated (0.25-AA and 0.50-AA treatments) and untreated (control) fish showed an increase in most saturated fatty acids (C14:0, C15:0 and C16:0) and in C20:4n-6 (arachidonic acid) in proportion with time. On the contrary, most of the remaining fatty acids underwent a progressive content loss throughout the storage period.

When the fatty acid groups of all three kinds of cobia fillets are considered (Table 4), frozen storage led to a progressive increase in the contents of SFA, while the presence of MUFA, PUFA and n-3 PUFA showed a decrease with the frozen storage time. Additionally, a progressive decrease with frozen storage time could be observed for the $n-3 / n-6$ ratio and the PI.
Frozen storage is known to be associated with fish lipid oxidation processes that could be explained as a result of the presence of pro-oxidant enzymes (lipoxygenases, peroxidases, and so on) and chemical pro-oxidant molecules (namely, hemoproteins and metal ions) in the fish muscle (Erickson, 1997; Sikorski and Kolakowski, 2000). Freezing and thawing may cause lysis of mitochondria and lysosomes and alter the distribution of enzymes, chemicals and factors affecting the rate of tissue reactions, so that deteriorative damage in frozen fish could be accelerated. Oxidative damage during frozen storage has been reported to be especially important in the case of unsaturated fatty acids, as a result of an increased susceptibility of the carboncarbon double bond to being attacked during the oxidation mechanism (Harris and Tall, 1994; Decker, 1998).

Previous research related to the frozen storage of fish has already shown that unsaturated lipids are likely to be oxidized. Thus, Serdaroglu and Felekoglu (2005) reported that SFA and PUFA presence increased and decreased, respectively, in minced sardine (Sardina pilchadus) muscle when stored at $-20{ }^{\circ} \mathrm{C}$ for up to 5 months. A similar behavior was found for both fatty acid groups present in frozen $\left(-30{ }^{\circ} \mathrm{C}\right)$ Spanish mackerel 
Table 4

Evolution* of fatty acid group ${ }^{* *}$ contents and ratio values during frozen storage of cobia fillets previously treated under different conditions ${ }^{\star * *}$

\begin{tabular}{|c|c|c|c|c|c|}
\hline \multirow{2}{*}{$\begin{array}{l}\text { Fatty acid } \\
\text { group or ratio }\end{array}$} & \multirow{2}{*}{ Treatment } & \multicolumn{4}{|c|}{ Frozen storage time (months) } \\
\hline & & 0 & 1 & 3 & 6 \\
\hline \multirow{3}{*}{$\Sigma$ SFA } & Control & $46.07 \pm 1.65 \mathrm{a}$ & $46.52 \pm 0.54 \mathrm{a}$ & $48.91 \pm 0.27 \mathrm{Bb}$ & $51.32 \pm 0.23 \mathrm{Bc}$ \\
\hline & $0.25-\mathrm{AA}$ & $45.72 \pm 0.29 a$ & $46.09 \pm 0.17 \mathrm{a}$ & $46.87 \pm 0.15 \mathrm{Ab}$ & $47.85 \pm 0.29 \mathrm{Ac}$ \\
\hline & $0.50-\mathrm{AA}$ & $46.13 \pm 0.19 a$ & $46.39 \pm 0.21 \mathrm{ab}$ & $46.60 \pm 0.21 \mathrm{Ab}$ & $47.73 \pm 0.14 \mathrm{Ac}$ \\
\hline \multirow{3}{*}{$\Sigma$ MUFA } & Control & $33.73 \pm 0.57 c$ & $32.80 \pm 0.19 c$ & $30.38 \pm 0.14 \mathrm{Ab}$ & $26.26 \pm 1.07 \mathrm{Aa}$ \\
\hline & $0.25-\mathrm{AA}$ & $33.73 \pm 0.21 c$ & $33.13 \pm 0.43 c$ & $31.59 \pm 0.19 \mathrm{Bb}$ & $28.33 \pm 0.27 \mathrm{Ba}$ \\
\hline & $0.50-A A$ & $33.62 \pm 0.30 c$ & $33.31 \pm 0.37 c$ & $32.05 \pm 0.28 \mathrm{Cb}$ & $29.81 \pm 0.25 \mathrm{Ca}$ \\
\hline \multirow{3}{*}{$\Sigma$ PUFA } & Control & $15.44 \pm 0.28 d$ & $14.51 \pm 0.18 c$ & $12.57 \pm 0.23 \mathrm{Ab}$ & $10.78 \pm 0.27 \mathrm{Aa}$ \\
\hline & $0.25-\mathrm{AA}$ & $15.48 \pm 0.55 c$ & $14.91 \pm 0.32 c$ & $13.71 \pm 0.18 \mathrm{Bb}$ & $12.68 \pm 0.13 \mathrm{Ba}$ \\
\hline & $0.50-A A$ & $15.43 \pm 0.28 d$ & $14.92 \pm 0.25 c$ & $14.20 \pm 0.21 \mathrm{Cb}$ & $13.22 \pm 0.24 \mathrm{Ca}$ \\
\hline \multirow{3}{*}{$\Sigma \mathrm{n}-3$ PUFA } & Control & $8.19 \pm 0.08 d$ & $7.32 \pm 0.06 \mathrm{Ac}$ & $5.69 \pm 0.06 \mathrm{Ab}$ & $4.33 \pm 0.05 \mathrm{Aa}$ \\
\hline & $0.25-\mathrm{AA}$ & $8.24 \pm 0.08 d$ & $7.71 \pm 0.06 \mathrm{Bc}$ & $6.79 \pm 0.06 \mathrm{Bb}$ & $5.86 \pm 0.05 \mathrm{Ba}$ \\
\hline & $0.50-A A$ & $8.14 \pm 0.08 d$ & $7.75 \pm 0.06 \mathrm{Bc}$ & $7.12 \pm 0.06 \mathrm{Cb}$ & $6.35 \pm 0.05 \mathrm{Ca}$ \\
\hline \multirow{3}{*}{$\Sigma$ n-3/ $\Sigma$ n-6 ratio } & Control & $1.13 \pm 0.01 d$ & $1.01 \pm 0.03 c$ & $0.83 \pm 0.02 \mathrm{Ab}$ & $0.67 \pm 0.01 \mathrm{Aa}$ \\
\hline & $0.25-\mathrm{AA}$ & $1.13 \pm 0.07 c$ & $1.07 \pm 0.07 c$ & $0.98 \pm 0.06 \mathrm{Bb}$ & $0.86 \pm 0.02 \mathrm{Ba}$ \\
\hline & $0.50-A A$ & $1.11 \pm 0.04 b$ & $1.08 \pm 0.05 b$ & $1.01 \pm 0.06 \mathrm{Bb}$ & $0.92 \pm 0.01 \mathrm{Ca}$ \\
\hline \multirow{3}{*}{ Polyene index } & Control & $0.28 \pm 0.01 d$ & $0.24 \pm 0.01 \mathrm{c}$ & $0.17 \pm 0.01 \mathrm{Ab}$ & $0.12 \pm 0.02 \mathrm{Aa}$ \\
\hline & $0.25-\mathrm{AA}$ & $0.28 \pm 0.01 c$ & $0.26 \pm 0.01 b$ & $0.21 \pm 0.01 \mathrm{Ba}$ & $0.18 \pm 0.01 \mathrm{Ba}$ \\
\hline & $0.50-\mathrm{AA}$ & $0.27 \pm 0.01 c$ & $0.26 \pm 0.01 c$ & $0.23 \pm 0.01 \mathrm{Bb}$ & $0.19 \pm 0.02 \mathrm{Ba}$ \\
\hline
\end{tabular}

* Mean values of three independent determinations \pm standard deviation. For each parameter, values in the same column followed by different capital letters $(A, B, C)$ denote significant $(p<0.05)$ differences as a result of the AA treatment. For each parameter, values in the same row followed by different small letters $(a, b, c, d)$ denote significant $(p<0.05)$ differences as a result of the frozen storage time. No letters are indicated when no significant $(p>0.05)$ differences are present.

${ }^{* *}$ Fatty acid group abbreviations: SFA (saturated fatty acids), MUFA (monounsaturated fatty acids), PUFA (polyunsaturated fatty acids). *** Treatment abbreviations: $0.25-\mathrm{AA}$ and 0.50 -AA correspond to frozen fillets previously immersed in $0.25 \%$ and $0.50 \%$ aqueous solutions of ascorbic acid, respectively.

(Scomberomorus commersoni) and white cheek shark (Carcharhinus dussumieri) fillets (Nazemroaya et al., 2009). A decrease in unsaturated fatty acid content, particularly PUFA, and lower $n-3 / n-6$ ratios were also found by Pirestani et al. (2010) in different kinds of fresh water fish species (Caspian kutum, golden grey mullet, common carp, pike perch and common kilka) belonging to the South Caspian sea during frozen $\left(-24^{\circ} \mathrm{C}\right)$ storage. Regarding the PI evolution during frozen storage, the present results agree with previous research where a decrease in this quality index was found for mackerel (Scomberomorus commerson), shark (Carcharhinus dussumieri) (Nazemroaya et al., 2009) and coho salmon (Oncorhynchus kisutch) (Ortiz et al., 2009).

A majority of the Western population does not consume adequate levels of n-3 fatty acids through natural dietary sources, such as fish. In this sense, a great interest has been assigned recently to the $n-3 / n-6$ ratio of foods included in the human diet. Its value has shown a great effect on the development of certain health problems (Weber, 1992; Simopoulos, 1994), with the recommended ratio for the whole diet closer to $1: 6(n-3 / n-6)$. Therefore, in spite of the fact that a marked decrease in the $n-3 / n-6$ content has been produced as a result of the frozen storage, cobia fillets can be considered as supporting an important and benefitial ratio value throughout the storage period.

\subsubsection{Effect of $A A$ dipping}

The results obtained which are related to the effect of the previous AA dipping on the quality of cobia fillets throughout the frozen storage period can be seen in Table 4.

Practically no effect could be observed during the $0-1$-month storage period. Thus, after the freezing process (0-month storage), no differences could be observed for any of the fatty acid groups and ratio values as a result of the previous $A A$ dipping treatment. After 1 month of frozen storage, 
a preserving effect of such treatment could be depicted for the n-3 PUFA content, although no differences could be observed in this parameter as a result of the AA concentration employed.

However, when fish fillets corresponding to three months of frozen storage are considered, a great effect of the previous AA treatment is observed. Thus, a preserving effect is observed for MUFA, PUFA and n-3 PUFA, this effect being stronger in the case of applying the highest $A A$ concentration (0.50-AA treatment). On the contrary, the proportion of SFA decreased in the treated fish, although no differences were found between both kinds of treated fish. Finally, the treated fish showed a higher $n-3 / n-6$ ratio and PI when compared to the untreated fish.

Results concerning a 6-month storage period are practically the same as those mentioned for 3 months. The only difference is that an increasing preserving effect of the AA dipping on the $n-3 / n-6$ ratio could be observed by increasing the $A A$ concentration of the aqueous dipping medium.

Industrial requirements are always related to the search for valuable and practical treatments that may lead to enhancing commercial possibilities. In this sense, an aqueous solution of a natural compound can be considered as most suitable, especially if such a compound includes properties like easy availability, low commercial cost and a wide range of permitted concentrations.

The present research agrees with previous research where a dipping treatment in an antioxidant solution was found useful in order to increase the quality retention and shelf life of frozen fish. Thus, AA and other natural organic acids have been successfully employed in different kinds of fish species such as Wels catfish (Silurus glanis) (Pourashouri et al. 2009) and horse mackerel (Trachurus trachurus) (Aubourg et al., 2004). Similarly, different kinds of vegetable extracts have been employed as previous soaking treatments such as rosemary extract and onion juice for sardine (Sardina pilchardus) mince (Serdaroglu and Felekoglu, 2005) and a flaxseed extract has been used on whole mackerel (Scomber scombrus) (Stodolnik et al., 2005). Finally, a previous washing in an aqueous solution of sucrose, sorbitol and polyphosphate was also successfully applied to minced silver carp (Asgharzadeh et al., 2010).

The effect of AA on farmed cobia fish has recently been studied according to the search for performed diets (Xiao et al., 2010); AA incorporation in the diet and its effect on different growing and developing parameters was analyzed. It could be observed that an increasing AA content in the diet could lead to an increased survival, weight gain, feed efficiency ratio and a muscular and hepatic AA concentration. In a related study (Ortiz et al., 2009), synthetic antioxidants (butylated hydroxytoluene and ethoxyquin) were replaced by natural ones (tocopherol isomers and rosemary extract) in the diet supplied to farmed coho salmon (Oncorhynchus kisutch); as a result, an increased rancidity stability could be observed in salmon fillets during a further frozen storage period at $\left(-18^{\circ} \mathrm{C}\right)$.

\section{CONCLUSIONS}

As a result of a frozen storage period of 6 months, a marked content decrease was found in the fatty acid groups such as MUFA, PUFA and n-3 PUFA, as well as in the $n-3 / n-6$ ratio. However, a preserving effect on such fatty acid parameters could be observed due to the AA treatment, which was greater when applying the $0.50 \%$ AA concentration as a soaking pre-treatment. Assessment of the PI indicated an increased lipid oxidation development as a result of the frozen storage time; however, this increase was partially inhibited by the previous AA soaking.

Consequently, the employment of $A A$ is firmly recommended as a previous treatment to the frozen storage of cobia fillets. Such a treatment could be applied alone or in combination with other protective and advanced strategies such as glazing, modified atmospheres, vacuum and active packaging, hydrostatic high pressure treatment, etc.

\section{ACKNOWLEDGEMENTS}

The authors appreciate the collaboration provided by the Persian Gulf and Oman Sea Ecology Research Center (Bandar Abbas, Iran).

\section{REFERENCES}

Ackman RG. 1990. Seafood lipids and fatty acids. Food Rev. Int. 6, 617-646.

Alasalvar C, Taylor K, Zubcov E, Shahidi F, Alexis M. 2002. Differentiation of cultured and wild sea bass (Dicentrarchus labrax): Total lipid content, fatty acid and trace mineral composition. Food Chem. 79, 145-150.

Álvarez V, Medina I, Prego R, Aubourg S. 2009. Lipid and mineral distribution in different zones of farmed and wild blackspot seabream (Pagellus bogaraveo). Eur. J. Lipid Sci. Technol. 111, 957-966.

AOAC. 2000. Official Methods of Analysis, $17^{\text {th }}$ edition. Association of Official Analytical Chemists, Arlington, Washington (USA).

AOAC. 2005. Official Methods of Analysis, $18^{\text {th }}$ edition. Association of Official Analytical Chemists. Gaithersburg, Maryland (USA).

Asgharzadeh A, Shabanpour B, Aubourg S, Hosseini H. 2010. Chemical changes in silver carp (Hypophthalmichthys molitrix) minced muscle during frozen storage: Effect of a previous washing process. Grasas y Aceites 61, 95-101.

Aubourg S, Losada V, Prego R. 2007. Distribution of lipids and trace minerals in different muscle sites of farmed and wild turbot (Psetta maxima). Int. J. Food Sci. Technol. 42, 1456-1464.

Aubourg S, Pérez-Alonso F, Gallardo J. 2004. Studies on rancidity inhibition in frozen horse mackerel (Trachurus trachurus) by citric and ascorbic acids. Eur. J. Lipid Sci. Technol. 106, 232-240. 
Aubourg, S. 1999. Effect of lipid damages on processed fish quality. Grasas y Aceites 50, 218-224.

Bligh E, Dyer W. 1959. A rapid method of total extraction and purification. Can. J. Biochem. Physiol. 37, 911917.

Celik M, Diler A, Kucukgulmez A. 2005. A comparison of the proximate compositions and fatty acid profiles of zander (Sander lucioperca) from two different region and climatic condition. Food Chem. 92, 637-641.

Chaouqy N, Gallardo J, El Marrakchi A, Aubourg S. 2008. Lipid damage development in anchovy (Engraulis encrasicholus) muscle during storage under refrigerated conditions. Grasas y Aceites 59, 309315.

Chow C-J, Yang J-I. 2011. The effect of process variables for production of cobia (Rachycentron canadum) skin gelatin hydrolysates with antioxidant properties. J. Food Biochem. 35, 715-734.

Davies A. 1997. Modified-atmosphere packaging of fish and fish products in Hall G (Ed.) Fish processing technology, pp. 200-223. Blackie Academic and Professional, London (UK).

Decker, E. 1998. Strategies for manipulating the prooxidative/antioxidative balance of foods to maximize oxidative stability. Trends Food Sci. Technol. 9, 241-248.

Duncan M, Craig S, Lunger A, Kuhn D, Salze G, McLean E. 2007. Bioimpedance assessment of body composition in cobia Rachycentron canadum (L. 1766). Aquacult. 271, 432-438.

Erickson, M. 1997. Lipid oxidation: Flavor and nutritional quality deterioration in frozen foods in Erickson $M$, Hung Y-C (Eds.) Quality in frozen food, pp. 141-173. Chapman and Hall, New York (USA).

Franks J, Warren J, Buchanan M. 1999. Age and growth of cobia, Rachycentron canadum, from the northern gulf of Mexico. Fish. Bull. 97, 459-471.

Giese J. 1996. Antioxidants: Tools for preventing lipid oxidation. Food Technol. 50, 73-80.

Greene D, Selivonchick D. 1987. Lipid metabolism in fish. Prog. Lipid Res. 26, 53-85.

Hamilton R, Kalu C, McNeill G, Padley F, Pierce J. 1998. Effects of tocopherols, ascorbyl palmitate, and lecithin on autoxidation of fish oil. J. Am. Oil Chem. Soc. 75, 813-822.

Harris, P. and Tall, J. 1994. Substrate specificity of mackerel flesh lipopolygenase. J. Food Sci. 59, 504506, 516.

Hwang K, Regenstein J. 1988. Protection of menhaden mince lipids from rancidity during frozen storage. $J$. Food Sci. 45, 1120-1124.

Ingemansson T, Olsson N, Kaufmann P. 1993. Lipid composition of light and dark muscle of rainbow trout (Oncorhynchus mykiss) after thermal acclimation: a multivariate approach. Aquacult. 113, 153-165.

Khristoferzen G. 1969. Polyunsaturated fatty acid content of fat of some Atlantic and Indian ocean fish. Voprosy Pitaniya 28, 86-87.

Kilinc B, Cakli S, Dincer T, Tolasa S. 2009. Microbiological, chemical, sensory, color, and textural changes of rainbow trout fillets treated with sodium acetate, sodium lactate, sodium citrate, and stored at $4{ }^{\circ} \mathrm{C}$. J. Aquat. Food Prod. Technol. 18, 3-17.

Kotb A, Abu Hadeed A. 1991. Omega-3 polyunsaturated fatty acid content of some popular species of Arabian gulf fish. Food Chem. 40, 185-190.

Liao I, Huang T, Tsai W, Hsueh C, Chang S, Leano E. 2004. Cobia culture in Taiwan: current status and problems. Aquacult. 237, 155-165.
Lin C, Lin C. 2005. Enhancement of the storage quality of frozen bonito fillets by glazing with tea extracts. Food Control 16, 169-175.

Liu S, Li D, Hong Z, Zhang C, Ji J, Gao J, Zhang L. 2009. Cholesterol, lipid content, and fatty acid composition of different tissues of farmed cobia (Rachycentron canadum) from China. J. Am. Oil Chem. Soc. 86, 1155-1161.

Madrid A, Madrid J, Madrid R. 1994. Chilling, freezing and ultra-freezing of fish and derivates in Madrid A (Ed.) Technology of fish and its derivatives, pp. 45103. AMV Ediciones y Mundi-Prensa Libros, S. A., Madrid (Spain).

Medina I, Gallardo J, Aubourg S. 2009. Quality preservation in chilled and frozen fish products by employment of slurry ice and natural antioxidants. Int. J. Food Sci. Technol. 44, 1467-1479.

Nazemroaya S, Sahari M, Rezaei M. 2009. Effect of frozen storage on fatty acid composition and changes in lipid content of Scomberomorus commersoni and Carcharhinus dussumieri. J. Appl. Ichthyol. 25, 91-95.

Ortiz J, Larraín MaA, Vivanco J, Aubourg S. 2009. Rancidity development during the frozen storage of farmed coho salmon (Oncorhynchus kisutch): Effect of antioxidant composition supplied in the diet. Food Chem. 115, 143-148.

Pearson A, Love J, Shorland F. 1977. "Warmed-over" flavor in meat, poultry and fish. Adv. Food Res. 23, 2-61.

Pirestani S, Sahari M, Barzegar M. 2010. Fatty acid changes during frozen storage in several fish species from South Caspian sea. J. Agric. Sci. Technol. 12, 321-329.

Pourashouri P, Shabanpour B, Aubourg S, Daghigh Rohi J, Shabani A. 2009. An investigation of rancidity inhibition during storage of Wels catfish (Silurus glanis) fillets by previous ascorbic and citric acid treatment. Int. J. Food Sci. Technol. 44, 1503-1509.

Rubio-Rodríguez N, Beltrán S, Jaime I, Diego S, Sanz M, Rovira J. 2010. Production of omega-3 polyunsaturated concentrates: A Review. Innov. Food Sci. Emerg. Technol. 11, 1-12.

Saito H, Ishihara K, Murase T. 1997. The fatty acid composition in tuna (bonito, Euthynnus pelamis) caught at three different localities from tropics to temperate. J. Sci. Food Agric. 73, 53-59.

Sanjuás M, Barros-Velázquez J, Aubourg S. 2011. Effect of different icing conditions on lipid damage development in chilled horse mackerel (Trachurus trachurus) muscle. Grasas y Aceites. 62, 436-442.

Serdaroglu M, Felekoglu E. 2005. Effects of using rosemary extract and onion juice on oxidative stability of sardine (Sardina pilchardus) mince. J. Food Qual. 28, 109-120.

Sikorski Z, Kolakowski E 2000. Endogenous enzyme activity and seafood quality: Influence of chilling, freezing, and other environmental factors in Haard $N$, Simpson B (Eds.) Seafood enzymes, pp. 451-487. Marcel Dekker, New York (USA).

Simopoulos A. 1994. Fatty acids in Goldberg I (Ed.) Functional foods, designer foods, pharmafoods, nutraceuticals, pp. 355-392. Chapman and Hall, New York (USA).

Stodolnik L, Stawicka A, Grzegorz G, Aubourg S. 2005. Rancidity inhibition study in frozen whole mackerel (Scomber scombrus) following flaxseed (Linum usitatissimum) extract treatment. Grasas y Aceites 56, 198-204. 
Trushenski J, Schwarz M, Lewis H, Laporte J, Delbos B, Takeuchi R, Sampaio L. 2011. Effect of replacing dietary fish oil with soybean oil on production performance and fillet lipid and fatty avid composition of juvenile cobia Rachycentron canadum. Aquacult. Nutr. 17, e437-e447.

Watanabe T. 1982. Lipid nutrition in fish. Comp. Biochem. Physiol. 73B, 3-15.

Weber P. 1992. Dietary fatty acids and eicosanoid biochemistry in Flick G, Martin R (Eds.) Advances in Seafood Biochemistry, pp. 181-184. Technomic Publishing, Lancaster ( $\mathrm{Pa}, \mathrm{USA})$.
Xia X-Z, Hong P-Z, Zhong C-H, Gao J-I, Zhang C-H. 2009. Application of HACCP system in frozen Rachycentron canadum linnaeu fillets processing. Modern Food Sci. Technol. 25, 954-956.

Xiao L, Mai K, Ai Q, Xu W, Wang X, Zhang W, Liufu Z. 2010. Dietary ascorbic acid requirement of cobia, Rachycentron canadum Linnaeus. Aquacult. Nutr. 16, 582-589.

Yang J-I, Ho H-Y, Chu Y-J, Chow C-J. 2008. Characteristic and antioxidant activity of retorted gelatin hydrolysates from cobia (Rachycentron canadum). Food Chem. 110, 128-136.

Recibido: 30/6/11 Aceptado: 7/9/11 